\title{
Pengaruh Macam Bahan Organik terhadap Nilai pH, pH0, Retensi P dan P tersedia pada Andisol Asal Ciater
}

\author{
Apong Sandrawati ${ }^{1}$, Teddy Marpaung ${ }^{2}$, Rina Devnita ${ }^{1}$, Yuliati Machfud ${ }^{1}$, dan Mahfud Arifin ${ }^{1}$
}

1) Departemen Ilmu Tanah dan Sumberdaya Lahan, Fakultas Pertanian, UNPAD

2) Alumni Program Studi Agroteknologi Pertanian, Fakultas Pertanian UNPAD

Jl. Raya Bandung Sumedang Km 21 Jatinangor

Korespondensi: apong.sandrawati@unpad.ac.id

\begin{abstract}
High phosphate $(\mathrm{P})$ retention is a major problem in Andisol that causes low phosphate availability. This study was conducted to determine the effect of various organic matters for $\mathrm{pH}_{0}, P$ retention and available $P$ on Andisol obtained from Ciater, West Java. Organic matters used in this experiment consisted of humic acid, straw compost, cow manure, goat manure and chicken manure. This experiment was conducted from April to September 2017 at Soil Physics Laboratory, Faculty of Agriculture, Padjadjaran University. The design used in this experiment was a non Factorial Completely Randomized Design (RAL) with eleven treatments and three replicates. The treatments were control, humic acid (2 $\mathrm{ml}$ and $4 \mathrm{ml}$ ), straw compost (5\% and 10\% of the soil weight), cow manure (5\% and $10 \%$ of the soil weight), goat manure (5\% and $10 \%$ of the soil weight) and chicken manure (5\% and $10 \%$ of the soil weight). The result showed that humic acid and various types of organic matter incubated for 3 months decreased $p H_{0}$ and $P$ retention, improved available $P$, but decreased $p H_{0}$ and $P$ retention as well as a negligible increase in available $P$.
\end{abstract}

Keywords: Andisol, incubation, Humic Acid, $\mathrm{pH}_{0}, \mathrm{P}$ Retention, available-P

\section{PENDAHULUAN}

Andisol tersebar luas di Indonesia terutama di wilayah dengan aktifitas vulkan. Sebaran tanah ini pada umumnya terdapat di wilayah dataran tinggi (ketinggian tempat di atas 700 meter dari permukaan laut) dengan suhu berkisar antara $16-22{ }^{\circ} \mathrm{C}$. Andisol berkembang dari hasil erupsi gunung berapi yang mempunyai mineral liat berupa mineral ordo kisaran pendek yang meliputi alofan, imogolit dan ferihidrit (Sukarman dan Dariah, 2014). Mineral tersebut membuat Andisol bermuatan variabel atau memiliki muatan yang tergantung $\mathrm{pH}$.

Salah satu kendala dalam pemanfaatan Andisol untuk budidaya pertanian adalah nilai retensi $\mathrm{P}$ yang tinggi. Nilai retensi $\mathrm{P}$ yang tinggi pada Andisol terjadi akibat kandungan mineral liat non kristalin (alofan, imogolit dan ferihidrit) yang tinggi pada tanah tersebut. Mineral non kristalin tersebut memiliki kemampuan mengikat $\mathrm{P}$ yang tinggi. Alofan mampu meretensi P hingga 97,8\% (Sukarman dan Dariah, 2014). Retensi P yang tinggi pada
Andisol berakibat kepada rendahnya $\mathrm{P}$ yang tersedia untuk tanaman.

Penurunan retensi $\mathrm{P}$ dapat dilakukan melalui peningkatan muatan negatif tanah. Andisol merupakan tanah yang bermuatan variabel atau memiliki muatan yang tergantung $\mathrm{pH}$. Peningkatan muatan negatif tanah dilakukan dengan meningkatkan $\mathrm{pH}$ tanah atau menurunkan nilai $\mathrm{pH}_{0}$ (Hartati dkk, 2003). Menurut Bohn et al. (1979), $\mathrm{pH}_{0}$ atau muatan titik nol (zero point of charge) adalah nilai $\mathrm{pH}$ pada saat muatan permukaannya secara elektrik netral atau nol. Status muatan titik nol merupakan salah satu indikator yang baik dalam pengelolaan tanah (Heil and Sposito, 1997).

Perubahan status muatan menjadi negatif merupakan salah satu alternatif yang dapat dilakukan untuk mengatasi permasalahan retensi P pada tanah Andisol. Penurunan nilai $\mathrm{pH}_{0}$ dan peningkatan nilai $\mathrm{pH}$ tanah akan meningkatkan selisih nilai $\mathrm{pH}_{0}$ dan $\mathrm{pH} \mathrm{H}_{2} \mathrm{O}$, sehingga nilai selisihnya makin negatif (Kosmulski, 2009). Bila nilai muatan titik nol 
(pHo) lebih rendah dari $\mathrm{pH}$ aktualnya, maka koloid tanah cenderung mempunyai afinitas yang tinggi untuk menjerap kation seperti Kalium (Bolan et al., 2003).

Salah satu bahan amelioran yang dapat diberikan untuk menurunkan $\mathrm{pH}_{0}$ yaitu bahan organik (Van Ranst et al., 1993). Peningkatan $\mathrm{pH}$ tanah akibat pemberian bahan organik terjadi karena selama proses dekomposisi akan dihasilkan senyawa organik bermuatan negatif yang mampu mengikat kation. Penurunan nilai $\mathrm{pH}_{0}$ akibat pemberian bahan organik terjadi karena bahan organik mengandung asam humat dan asam fulvat yang mempunyai $\mathrm{pH}_{0}$ rendah (Uehara dan Gillman, 1981). Hartati dkk (2003) menyatakan bahwa pemberian bahan organik berupa pupuk kandang, mampu menurunkan $\mathrm{pH}_{0}$, retensi fosfat dan meningkatkan Ptersedia pada Oxisol dengan inkubasi selama 3 bulan.

Pemberian bahan organik tanah mampu mempengaruhi fiksasi atau retensi $\mathrm{P}$ melalui beberapa cara antara lain mengganti ion fosfat dengan ion humat pada kompleks jerapan, pembentukan kompleks fosfo-humat, pelapisan seskuioksida oleh bahan humus sehingga tidak tersedia tapak untuk menjerap $\mathrm{P}$ (Havlin et al., 2005). Penurunan retensi $\mathrm{P}$ akibat pemberian asam humat dan berbagai jenis bahan organik melalui mekanisme pengkhelatan atau pembentukan kompleks dengan $\mathrm{Al}$ dan Fe.

Tan (1998) menyatakan bahwa asamasam organik mampu mengkhe-lat ion $\mathrm{Al}$ dan Fe yang mengikat fosfat sehingga pengikatan fosfat berkurang dan meningkatkan ketersediaan $\mathrm{P}$ dalam tanah. Yulnafatmawita dkk (2005) menunjukkan bahwa pemberian bahan organik berupa pupuk kandang ayam yang diinkubasi pada Andisol Ladang Laweh mampu meningkatkan P-tersedia. Irawan dkk (2016) menambahkan bahwa bahan organik dapat meningkatkan P-tersedia pada Andisol dari 5,73 ppm hingga 15,49 ppm.
Pemberian berbagai jenis bahan organik pada penelitian ini diharapkan mampu meningkatkan nilai $\mathrm{pH}$, menurunkan nilai pH0, menurunkan retensi $\mathrm{P}$, dan meningkatkan $\mathrm{P}$ tersedia pada tanah Andisol asal Ciater.

\section{BAHAN DAN METODE}

\subsection{Waktu dan Tempat Penelitian}

Penelitian dilaksanakan pada akhir bulan April 2017 sampai September 2017. Analisis tanah dilakukan di Laboratorium Kesuburan Tanah dan Nutrisi Tanaman. Penelitian ini dilaksanakan pada skala laboratorium. Pengambilan contoh tanah dilakukan di area Perkebunan Teh PTPN VIII-Ciater Kabupaten Subang, Jawa Barat. Percobaan dan analisis laboratorium dilakukan di Laboratorium Departemen Ilmu Tanah dan Manajemen Lahan, Fakultas Pertanian Universitas Padjadjaran.

\subsection{Alat dan Bahan}

Alat yang digunakan dalam penelitian ini yaitu peralatan lapangan (cangkul, label, plastik, karung, alat tulis dan kamera), peralatan analisisis laboratorium (botol film, botol kocok, gelas ukur, pipet ukur, mesin pengocok, timbangan analitik, timbangan digital, botol semprot, $\mathrm{pH}$ meter, mesin sentrifuge, tabung sentrifuge, tabung reaksi, spektrofotometer dan kertas saring), peralatan inkubasi (polybag ukuran $3 \mathrm{~kg}$, tali atau karet pengikat, sekop kecil), dan peralatan yang digunakan untuk pengolahan data berupa komputer dengan perangkat lunak SPSS versi 17.0.

Bahan yang digunakan dalam penelitian ini yaitu tanah Andisol asal Ciater, SubangJawa Barat, amelioran berupa asam humat dan bahan organik yang terdiri atas: pupuk kandang sapi, pupuk kandang kambing, pupuk kandang ayam, pupuk kompos jerami dan bahan-bahan kimia untuk menunjang analisis di laboratorium. 


\subsection{Rancangan Percobaan}

Percobaan ini menggunakan metode Rancangan Acak Lengkap (RAL) non faktorial. Percobaan ini terdiri atas 11 perlakuan, yang terdiri atas:
A. Tanpa perlakuan (kontrol)
B. Asam humat $2 \mathrm{ml}$ per polybag
C. Asam humat $4 \mathrm{ml}$ per polybag
D. Pupuk kompos jerami dosis $5 \%$ dari berat tanah
E. Pupuk kompos jerami dosis $10 \%$ dari berat tanah
F. Pupuk kandang sapi dosis 5\% dari berat tanah
G. Pupuk kandang sapi $10 \%$ dari berat tanah
H. Pupuk kandang kambing dosis 5\% dari berat tanah
I. Pupuk kandang kambing $10 \%$ dari berat tanah
J. Pupuk kandang ayam dosis 5\% dari berat tanah
K. Pupuk kandang ayam 10\% dari berat tanah

Seluruh perlakuan diulang 3 (tiga) kali ulangan, sehingga diperoleh 33 unit satuan percobaan.

\subsection{Rancangan Analisis}

Analisis percobaan dalam penelitian ini menggunakan model linear RAL non faktorial, dengan model linear (Gomez dan Gomez, 1995) sebagai berikut:

$$
\begin{gathered}
\mathbf{Y}_{\mathbf{i j k} \mathbf{k}}=\boldsymbol{\mu}+\boldsymbol{\alpha}_{\mathbf{i}}+\boldsymbol{\varepsilon}_{\mathbf{i j}} \\
\mathrm{i}=1,2, \ldots, 11 \mathrm{rdan} \mathrm{j}=1,2,3
\end{gathered}
$$

Keterangan :

$$
\begin{array}{c:l}
\mathrm{Y}_{\mathrm{ij}} & : \text { hasil pengamatan faktor perlakuan } \\
\mu & : \text { pada taraf ke-i pada ulangan ke-j } \\
\alpha_{\mathrm{i}} & : \text { nilai tengah sebenarnya pengaruh } \\
& \\
\varepsilon_{\mathrm{ij}} & : \text { faktor perlakuan pada taraf ke-i } \\
&
\end{array}
$$

Pengujian pengaruh perbedaan rata-rata perlakuan dilakukan dengan uji $\mathrm{F}$ pada taraf nyata $5 \%$.

\subsection{Pelaksanaan Penelitian}

Sampel tanah diambil dari lokasi Afdeling Ciater, PTPN VIII Subang, Jawa Barat. Sampel tanah yang diambil yaitu contoh tanah terganggu (disturbed sampled) dari tiga titik lokasi yang kemudian dikompositkan. Sampel tanah diambil pada kedalaman 0-60 cm dengan menggunakan cangkul.

Bahan amelioran yang akan digunakan pada penelitian ini adalah asam humat, pupuk kandang sapi, pupuk kandang kambing, pupuk kandang ayam dan pupuk kompos jerami. Asam humat yang digunakan dalam penelitian ini berasal dari PT Humat Agro Lesatari. Pupuk kompos jerami, pupuk kandang sapi, pupuk kandang kambing dan pupuk kandang ayam yang digunakan dalam penelitian ini diperoleh dari Kebun Percobaan Ciparanje. Persiapan yang dilakukan terhadap bahan amelioran adalah melakukan analisis laboratorium terhadap masing-masing amelioran tersebut.

Persiapan terhadap media inkubasi berupa tanah Andisol asal Ciater, Subang-Jawa Barat dilakukan dengan mencampur dan mengaduk tanah hingga merata. Setelah itu menimbang tanah sebanyak $1,5 \mathrm{~kg}$ dan menambahkan asam humat dan bahan organik berupa pupuk kompos jerami, pupuk kandang sapi, pupuk kandang kambing, dan pupuk kandang ayam sesuai perlakuan yang ditentukan, lalu diaduk merata. Setelah itu tanah yang telah tercampur dengan amelioran bahan organik sesuai perlakuan kemudian dimasukkan ke dalam polybag berukuran 3 kg. Polybag lalu diikat dan diberi label sesuai perlakuan. Media diletakkan sesuai tata letak percobaan dalam ruangan yang terjaga kelembabannya.

Inkubasi tanah dilakukan selama 3 bulan atau 90 hari. Pengambilan sampel tanah untuk keperluan analisis akhir dilakukan pada akhir masa inkubasi. Sampel tanah untuk keperluan analisis akhir diambil sebanyak 100 gram dari masing-masing polybag. 


\section{HASIL DAN PEMBAHASAN}

\subsection{Hasil Analisis Tanah Awal}

Hasil analisis tanah awal menunjukkan nilai retensi $\mathrm{P}$ yang tergolong sangat tinggi sebesar 95\%, P-tersedia 1,53 ppm (sangat rendah) kandungan C-organik tergolong sangat tinggi $(7,63 \%)$, bobot isi tanah tergolong rendah sebesar 0,78 g.cm ${ }^{3}$ dan $\mathrm{Al}+$ $1 / 2 \mathrm{Fe}$ oksalat sebesar $8,5 \%$. Hasil analisis tanah awal memperlihatkan bahwa tanah yang digunakan dalam percobaan ini memenuhi kriteria sifat tanah andik yaitu retensi $\mathrm{P} \geq 85 \%, \mathrm{Al}+1 / 2 \mathrm{Fe}$ oksalat $\geq 2 \%$ dan bobot isi rendah atau $\leq 0,90 \mathrm{~g} \cdot \mathrm{cm}^{3}$ (Hardjowigeno, 2003; Rachim dan Arifin, 2011).

Berdasarkan hasil analisis tanah awal, tanah yang digunakan dalam percobaan ini memiliki $\mathrm{pH}_{2} \mathrm{O}$ sebesar 4,53 dan $\mathrm{pH} \mathrm{KCl}$ sebesar 4,52 sehingga selisih $(\Delta) \mathrm{pH}$ sebesar 0,01 . Hal tersebut menunjukkan bahwa tanah yang digunakan dalam percobaan ini bermuatan variabel karena memiliki nilai $\Delta$ pH antara -0,5 sampai 0,5 (Uehara dan Gillman, 1986). Menurut Parfitt (1980), muatan variabel pada Andisol berasal dari bahan organik, alofan dan besi oksida (ferihidrit).

\subsection{Kemasaman Tanah $\left(\mathrm{pH} \mathrm{H}_{2} \mathrm{O}\right)$}

Hasil pengukuran pH tanah setelah inkubasi dapat dilihat pada Tabel 1. Perbandingan nilai $\mathrm{pH}_{2} \mathrm{O}$ tanah sebelum dan setelah diinkubasi selama 3 bulan dapat dilihat pada Gambar 1. Penambahan berbagai macam bahan organik dapat meningkatkan nilai $\mathrm{pH}$ tanah Andisols Ciater. Pada bahan organik tertentu, terdapat gugus fungsional karboksil yang dapat melepas ataupun mengikat $\mathrm{H}^{+}$(Stevenson and Vance, 1989 dalam Wong and Swift, 2001). Hal ini yang mendasari kemampuan bahan organik sebagai buffer untuk nilai $\mathrm{pH}$. Sesuai dengan fungsi buffernya, semua perlakuan bahan organik dapat meningkatkan nilai $\mathrm{pH} \quad \mathrm{H}_{2} \mathrm{O}$ tanah yang semula masam $(\mathrm{pH}=4,48)$.

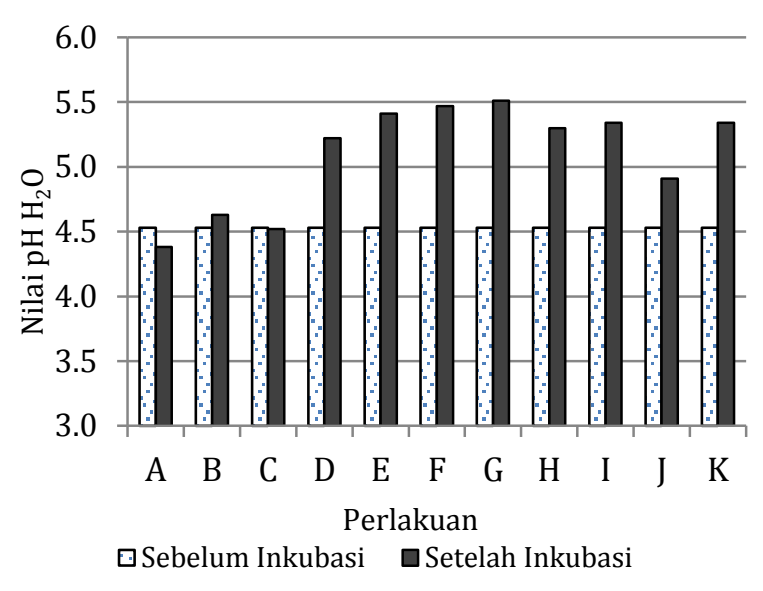

Gambar 1 Histogram hasil analisis $\mathrm{pH}_{2} \mathrm{O}$ sebelum dan setelah inkubasi

\subsection{Nilai pH0}

Hasil uji statistik menunjukkan bahwa pemberian perlakuan asam humat dan berbagai macam bahan organik setelah 3 bulan inkubasi tidak berpengaruh nyata terhadap penurunan nilai $\mathrm{pH}_{0}$. Nilai $\mathrm{pH}_{0}$ setelah 3 bulan inkubasi dapat dilihat pada Tabel 1.

Tabel 1 Nilai $\mathrm{pH}$ Aktual Tanah dan $\mathrm{pH}_{0}$ pada Berbagai Perlakuan Setelah 3 Bulan Inkubasi

\begin{tabular}{cccc}
\hline Perlakuan & $\mathrm{pH} \mathrm{H}_{2} \mathrm{O}$ & $\mathrm{pH}_{0}$ & $\mathrm{pH}_{0}-\mathrm{pH} \mathrm{H}_{2} \mathrm{O}$ \\
\hline $\mathrm{A}$ & 4,38 & 5,25 & 0,87 \\
$\mathrm{~B}$ & 4,63 & 4.21 & $-0,42$ \\
$\mathrm{C}$ & 4,52 & 4.03 & $-0,49$ \\
$\mathrm{D}$ & 5,22 & 4.29 & $-0,93$ \\
$\mathrm{E}$ & 5,41 & 4,22 & $-1,19$ \\
$\mathrm{~F}$ & 5,47 & 4,80 & $-0,67$ \\
$\mathrm{G}$ & 5,51 & 4,06 & $-1,45$ \\
$\mathrm{H}$ & 5,30 & 4,06 & $-1,24$ \\
$\mathrm{I}$ & 5,34 & 3,95 & $-1,39$ \\
$\mathrm{~J}$ & 4,91 & 3,89 & $-1,02$ \\
$\mathrm{~K}$ & 5,34 & 3,87 & $-1,47$ \\
\hline
\end{tabular}

Jika dibandingkan dengan nilai $\mathrm{pH}_{0}$ pada analisis awal yaitu 5,25 terjadi penurunan nilai $\mathrm{pH}_{0}$ hampir pada setiap perlakuan kecuali pada perlakuan kontrol dan pupuk kandang sapi dosis $5 \%$ dari berat tanah (F). 
Pemberian asam humat dan macam bahan organik cenderung menurunkan nilai $\mathrm{pH}_{0}$ menjadi lebih rendah dari pH aktualnya. Hasil analisis (Tabel 1) menunjukkan bahwa selisih antara $\mathrm{pH}_{0}$ dan $\mathrm{pH} \mathrm{H}_{2} \mathrm{O}$ pada berbagai perlakuan bernilai negatif. Hal tersebut menunjukkan bahwa koloid tanah bermuatan negatif. Sementara pada tanpa perlakuan (A) memiliki $\mathrm{pH}_{0}$ sebesar 5,25 yang melebihi $\mathrm{pH}$ aktualnya sehingga selisihnya menunjukkan nilai positif. Menurut Bohn et al. (1979), apabila pH aktual tanah kurang dari MTN atau $\mathrm{pH}_{0}$ maka muatan permukaan adalah positif.

Penurunan $\mathrm{pH}_{0}$ tersebut terjadi karena asam humat dan macam bahan organik yang diberikan mengandung bahan-bahan dengan nilai $\mathrm{pH}_{0}$ rendah sehingga akan menurunkan muatan titik nol atau $\mathrm{pH}_{0}$ tanah (Uehara dan Gillman, 1981). Penurunan nilai $\mathrm{pH}_{0}$ juga berkaitan dengan proses dekomposisi terhadap bahan organik yang diberikan. Selama proses dekomposisi bahan organik akan dihasilkan asam-asam organik. Gugus fungsional pada asam-asam organik seperti hidroksil $(-\mathrm{OH})$ dan karboksil $(-\mathrm{COOH})$ mempunyai afinitas tinggi terhadap $\mathrm{Al}$ dan $\mathrm{Fe}$ (Tan, 2003).

Jerapan spesifik asam organik oleh oksida-hidrus Al dan Fe, kompleksasi Al dan Fe serta reaksi protonasi-deprotonasi asamasam organik dapat menyebabkan meningkatnya muatan negatif pada permukaan koloid dan nilai $\mathrm{pH}_{0}$ menjadi turun (Haynes dan Mokolobate, 2001; Huang et al., 2005). Gillman (1985) menyatakan bahwa penambahan bahan organik dalam jumlah besar pada tanah bermuatan variabel akan menurunkan $\mathrm{pH}_{0}$ melalui jerapan anion organik yang menutupi sebagian permukaan positifnya sehingga akan lebih meningkatkan muatan negatif.

\subsection{Retensi P}

Pemberian perlakuan asam humat dan berbagai macam bahan organik setelah 3 bulan inkubasi dapat menurunkan nilai retensi $P$ (Gambar 2). Namun, dengan pengujian statistik, macam dan dosis bahan organik tidak berpengaruh nyata dalam menurunkan nilai retensi P. Penambahan jumlah taraf dosis dan ulangan dapat disarankan pada percobaan berikutnya.

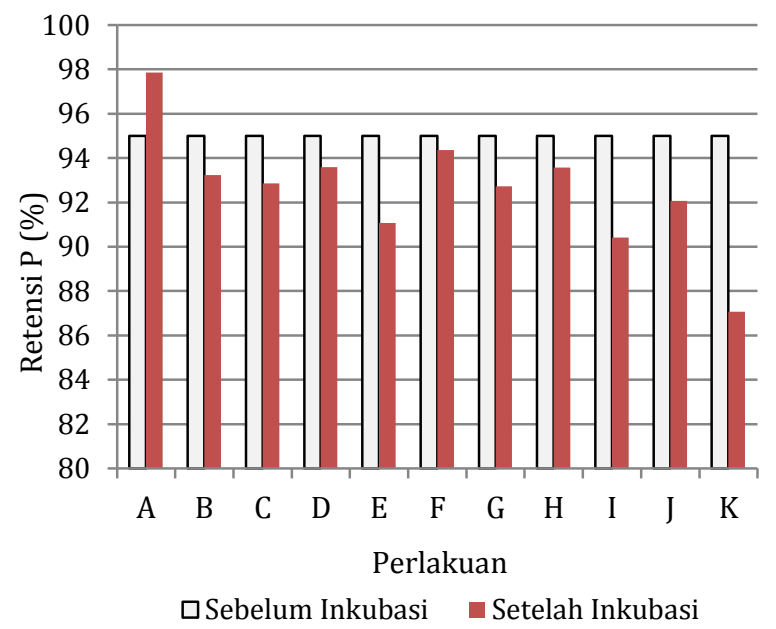

Gambar 2 Histogram hasil analisis Retensi P (\%) sebelum dan setelah inkubasi

Berdasarkan Gambar 2, peningkatan dosis bahan organik dapat menurunkan retensi $\mathrm{P}$ lebih besar. Hal ini menunjukkan bahwa pemberian asam humat dan berbagai jenis bahan organik juga dapat digunakan sebagai bahan amelioran untuk menurunkan retensi P. Perlakuan Pupuk kandang ayam 10\% dapat menurunkan nilai retensi $\mathrm{P}$ terbesar.

Penurunan nilai retensi P disebabkan oleh asam-asam organik yang dihasilkan dari proses dekomposisi bahan organik yang ditambahkan. Asam-asam organik yang dihasilkan mampu menetralisir muatan positif pada permukaan oksida $\mathrm{Al}$ dan Fe (Stevenson, 1994). Asam organik juga mampu membentuk kompleks atau khelat dengan ion $\mathrm{Al}$ dan $\mathrm{Fe}$ (Juo dan Fox, 1977; Tan, 1998).

Berdasarkan penelitian Devnita (2010), penambahan amelioran bermuatan negatif dalam jumlah besar ke dalam tanah akan memblok muatan positif pada koloid tanah dan mengisi tapak-tapak pertukaran sehingga koloid tanah menjadi lebih negatif dan fosfat yang teretensi menjadi terlepas. 


\subsection{Kadar P tersedia}

Penambahan bahan organik dengan macam dan dosis yang berbeda tidak berpengaruh nyata dalam peningkatan Ptersedia pada tanah. Namun, apabila dibandingkan antara nilai P-tersedia pada analisis awal (1,53 ppm), terjadi peningkatan nilai P-tersedia pada hampir pada setiap perlakuan bahan organik.

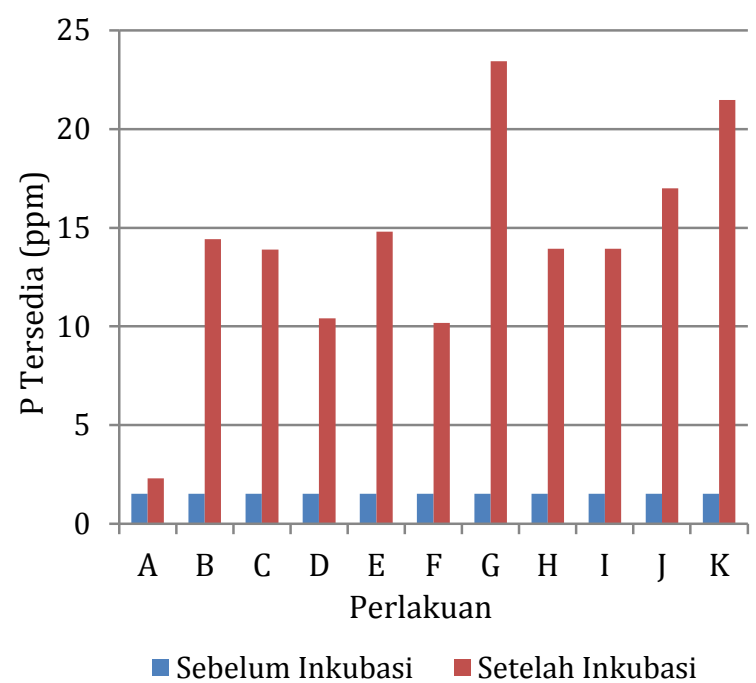

Gambar 3 Histogram hasil analisis P-tersedia (ppm) sebelum dan setelah inkubasi

Peningkatan P-tersedia terjadi akibat pengaruh asam-asam organik yang dihasilkan selama proses dekomposisi bahan organik (pupuk kandang sapi, pupuk kandang kambing, pupuk kandang ayam dan pupuk kompos jerami, dan asam humat). Asam-asam organik mampu mengkhelat ion $\mathrm{Al}$ dan $\mathrm{Fe}$ yang mengikat fosfat, dampaknya pengikatan fosfat akan berkurang dan terjadi pelepasan $\mathrm{P}$ sehingga P menjadi lebih tersedia (Tan, 1998). Hal tersebut sejalan dengan pernyataan Hastuti (2003) yang menyatakan bahwa penguraian bahan organik menghasilkan asam humat dan asam fulvat sehingga $P$ yang terikat dapat dilepaskan dan menjadi tersedia dalam tanah. Selain itu, kandungan $\mathrm{P}_{2} \mathrm{O}_{5}$ pada asam humat dan masing-masing bahan organik juga turut berkontribusi meningkatkan P dalam tanah.

\section{KESIMPULAN}

Pemberian berbagai macam bahan organik dapat meningkatkan nilai $\mathrm{pH} \mathrm{H}_{2} \mathrm{O}$ dan menurunkan pHO selama inkubasi 3 bulan. Penambahan bahan organik juga dapat menurunkan retensi P (\%) dan meningkatkan P-tersedia (ppm) dalam tanah. Walaupun terjadi perubahan dalam penilaian parameter uji $\left(\mathrm{pH} \mathrm{H}_{2} \mathrm{O}, \mathrm{pH}\right.$, retensi $\mathrm{P}$, dan kadar Ptersedia), secara statistik pengaruhnya tidak signifikan. Untuk memperkecil nilai galat, dapat dilakukan dengan mengurangi macam bahan organik dan meningkatkan jumlah taraf dosis.

\section{DAFTAR PUSTAKA}

Bohn, H. L., McNeal, B. L., and O'Connor, G. A., 1979. Soil Chemistry. John Willey \& Sons, New York.

Bolan, N.S., Adriano, D.C., and Curtin, D. 2003. Soil acidification and liming interaction with nutrient and heavy metal transformation and bioavailability. Advance of Agronomy, 78: $215-272$.

Devnita, R. 2010. Pengaruh Berbagai Bahan Amelioran Terhadap $\mathrm{pH}_{\mathrm{o}}$, Retensi $\mathrm{P}$ dan KTK Pada Beberapa Andisol di Jawa Barat. Fakultas Pertanian. Universitas Padjajaran

Gomez, K.A. dan A.A. Gomez. 1995. Prosedur Statistik untuk Penelitian Pertanian Terjemahan dari Statistical Procedures for Agriculture Research. Terjemahan E. Sjamsuddin dan J.S. Baharsjah. Universitas Indonesia Press, Jakarta.

Gillman, G. P. 1985. Influence of Organic Matter and Phosphate Content on the Point of Zero Charge of Variable Charge Components in Oxidic Soils. Aust. J. of Soil Res. 23:643-646. 
Hardjowigeno, S. 2003. Klasifikasi Tanah dan Pedogenesis. Jakarta: Akademika Pressindo.

Hardjowigeno, S. 2010. Ilmu Tanah. Jakarta: Akademika Pressindo.

Hartati, S., S. Minardi, dan W. Wulandari. 2003. The effect of amelioran kinds and dosages to oxisol's zero charge point and phosphate retention. Jurnal Sains Tanah 3(2): 73-77.

Haynes, R. J., and M. S. Mokolobate. 2001. Amelioration of $\mathrm{Al}$ toicity and $\mathrm{P}$ deficiency in acid soils by additions of organic residues: a critical review of the phenomenon and the mechanism involved. Nutr. Cycl Agroecosyst 59: 47-63.

Huang, P. M., M. Wand and C. Chiu. 2005. Soil mineral-organic matter-microbe interactions: impacts on biogeochemical processes and biodiversity in soils. Pedobiologia, 49 : 609-635.

Irawan, A., Y. Jufri, dan Zuraida. 2016. Pengaruh pemberian bahan organik terhadap perubahan sifat kimia Andisol, pertumbuhan dan produksi gandum (Triticum eastivum L.). Jurnal Kawista 1(1): 1-9.

Juo, A. S. R. and R. L. Fox. 1977. Phosphate sorption characteristic of some benchmark soils of West Africa. Soil Sci. 124, 370-376.

Kosmulski, M. 2009. The $\mathrm{pH}$ dependent charge surface charging and points of zero charge. IV. update and new approach. Jurnal of Colloid and Interface Science, 3337: 439-448.

Parfitt, R.L. 1980. Chemichal properties of variable charge soils. In Theng, B.K.G (Ed). Soils with Variable Charge. New Zealand Society of Soil Science. p: 167 - 194.
Rachim, D.A. dan Arifin, M. 2011. Dasar-dasar Klasifikasi Taksonomi Tanah. Bandung: pustaka Reka Cipta.

Stevenson, F. J. 1994. Humus Chemistry : Genesis, Composition, Reactions. 2nd Edition. John Willey \& Sons Inc. New York.

Sukarman, dan A. Dariah. 2014. Tanah Andosol Di Indonesia: Karakteristik, Potensi, Kendala, dan Pengelolaanya Untuk Pertanian. Bogor: Balai Besar Penelitian dan Pengembangan Sumberdaya Lahan Pertanian.

Tan, K. H. 1998. Dasar-dasar Kimia Tanah. Gadjah Mada University Press. Yogyakarta.

Tan, K. H. 2003. Humic Matter in the Soil and the Environment: Principles and Controversies. Marcel Dekker, Inc. New York. USA.

Uehara, G and G.P. Gillman. 1981. The mineralogy, chemistry and physics of tropical soils with variable charge clays. Westview Press. Colorado.

Van Ranst, E., F. De Connick and J. Debaveye. 1993. Implication of charge properties and chemical management of volcanic ash soils in West Cameroon. Proc. In $2^{\text {nd }}$ African Soil Sci. Soc. Conf. 255-264.

Wong, M. T. F. and Swift, R.S. 2001. Application of fresh and humified organic matter to ameliorate soil acidity. In Swift, R.S and Spark, K,M (eds). Understanding and Managing Organic Matter in Soils, Sediment, and Waters. St. Paul : International Humic Substances Society. p. $235-242$.

Yulnafatmawita, Lusi Maria, Junaidi, Yusmini, dan Nurhajati Hakim. 2005. Peranan Bahan Organik Dalam Pembebasan PTerikat Pada Tanah Andisol. Jurnal Solum 2(2): 20-24. 